\title{
Beyond Shakespeare's land of ire: Revisiting Ireland in English Renaissance drama
}

\section{Stephen O'Neill $\mathbb{D}$}

Maynooth University

Correspondence

Stephen O'Neill, Maynooth University Department of English, Ireland.

Email: stephen.oneill@mu.ie

\begin{abstract}
There has been much critical work on the symbolic centrality of Ireland to English Renaissance literature and drama. To focus on the latter, Shakespeare's histories have been read topically in terms of the contemporaneous Irish wars and also more historically, in terms of English colonialism in Ireland. Topical readings have been followed by allegorical approaches with, for instance, attention to Othello's "ghostly Irish subtext" (Hadfield, 1997) or Troilus and Cressida's memories of Elizabethan conflict in Ireland (Parker, 1996). Such interpretations suggest scholarly imaginativeness, the discovery of surprising meaning about a text we thought we knew, albeit within a Shakespeare-centric frame. They further suggest the capacity of Ireland to enter a play's imaginary-as problem, as image, as other world. At stake here, then, are interrelated questions about what Ireland is doing in English Renaissance drama, where and when we expect to find it, and how we read it. This essay re-examines the question of why and how Ireland features in plays by Shakespeare and other early modern dramatists. This deceptively simple question is intended to revisit some assumptions that underpin current critical understandings. Why Ireland features in plays has been largely understood as a function of historical contexts and processes: critics and scholars have turned to these as an important site of explanation, with the early modern colonialist discourse on Ireland given special prominence as a determinant of meaning. However, this focus has sidelined other considerations. This article argues for a broadening of context, beyond a focus on topical resonance, to allow for a consideration of dramatic genre and
\end{abstract}


form, the imitative nature of dramatic writing, and the theatre companies themselves, as important factors that shaped how a text and context like Ireland and the Irish found its way into a play. This approach treats representations as a series of reciprocal markings, intertextual echoes, and foregrounds the capacity of a play to make meaning within its own frame. The objective here is less about discounting the political and ideological work of Renaissance plays than about exploring their possibilities to (re)imagine the early modern "land of ire."

\section{1 | SOIL}

The stage is covered with a layer of top soil, but with the suggestion of hidden depths. This is the pre-scene to Druid Shakespeare, which offers an opening point for reconsidering how and indeed why Ireland figures in Shakespeare and early modern drama. ${ }^{1}$ Druid is a Galway-based theatre company with an international profile-their marathon production of the Henriad in 2015 toured in Ireland and in North America. The production's use of soil on the stage-a staging choice Druid had previously deployed for their Synge and Murphy productions-suggests a range of meanings and invites several interpretations. It lends the plays a symbolic materiality, grounding them in Ireland. The stage soil also literalises the earthy metaphors of Shakespeare's Richard II (1595), as in the king's declaration, "We must supplant those rough rug-headed kerns, /Which live like venom where no venom else/But only they have privilege to live" (2.1.156-59), an allusion to the legend of St. Patrick banishing snakes from Ireland, but one that gives rise to a proverbial association of the Irish as themselves poisonous. ${ }^{2}$ Other earthly metaphors come to mind, such as Richard's figuring of his return to England, "I weep for joy/To stand upon my kingdom once again [...] This earth shall have a feeling" (3.2.4-5; 24). Richard's affective affinity with the soil conveys a sense of home, which is secured through the implicit contrast with the Ireland that he has left behind. England's soil is understood as constitutive not just of an English body politic or social formation, but of Englishness as a race (Feerick, 2014, pp. 17-20) too. And if, as Sir John Perrot, Lord Governor of Ireland, claimed "the soyle and scituaiton of the contrie" shapes "men's dispositions" (quoted in Feerick, 2014, p. 18), then inhabiting or planting oneself in another soil could bring about an alteration, or a degeneration of the new English settlers in Ireland and also their descendants. Such reversals are registered elsewhere in Shakespearean histories, where Irish soil is not the recipient of Englishmen's tears so much as their blood, as in the news from Ireland in Shakespeare's Henry VI (c. 1590) that "Th'uncivil kerns of Ireland are up in arms/And temper clay with blood of Englishmen" (Scene 9, 310-11). Druid's onstage soil might also be interpreted as a great leveller, the stuff that all humans, English kings, and Irish kerns end up under, a point performances at Kilkenny Castle Yard made manifest with the offstage burial of King Richard during the interval between Richard II and 1 Henry IV.

Druid were at once suggesting that their production signalled an Irish iteration or revision of Shakespeare's English histories and, at the same time, placed a question mark around that interpretation, as if to say, why would there be a need for an "Irish Shakespeare," and what would this even look like? This question in turn prompts an inquiry into the historical relation between Shakespeare and Ireland as a place and a concept, the Elizabethan "land of ire." One of the key ways Druid's production pushes the question about why Ireland figures in Shakespeare and early modern drama in new directions is through omissions, so no gallivanting Captain MacMorris, with his fiery questions about his nation, a cut that, although not unusual in the staging history of Henry V (1599), in Druid's hands suggested an avoidance of the immediately topical, as in the critical tradition of regarding Henry $V$ as a play ostensibly 
about the wars in 1590s Ireland. Rather, the production's interest lay in exploring subtler manifestations of Ireland within the texture of these plays.

The programme note, penned by journalist and theatre critic Fintan O'Toole, established some reception parameters for the production of these Shakespearean histories on Irish soil. O'Toole suggested that the Nine Years War in Ireland was to Elizabethan culture what the Vietnam war was to 1960s American culture. The Irish wars infiltrated the Elizabethan cultural imaginary of which Shakespeare's plays were a part. O'Toole sketches the hermeneutics of reading the Irish wars in the plays - "to go looking for them is to miss the point of their obviousness and ubiquity" (O'Toole, 2015), he argues. "There is a temptation, in any sustained Irish exploration of these plays, to seize on the few outward Irish references and display them as trophies," but he concludes, "in truth everything in these plays is Irish-just as everything in them is French and Polish and German and Japanese" (O'Toole, 2015). O'Toole rehearses the familiar argument that we make Shakespeare our contemporary or, in this case, our countryman, and warns against distinctly Irish readings of the plays, "There is no need for special pleading," he concludes, perhaps an allusion to Druid's omission of overt references to Ireland.

While not wanting to make too much of O'Toole's programme note, it foregrounds aspects of Druid's approach to Shakespeare, which is-and is not-about Ireland in Shakespeare, where Ireland is at once covert and overt, fleetingly present, yet curiously overdetermined. Criticism engages in its own over-determinations of Ireland, and of Shakespeare. James Shapiro claims that "For the past century," MacMorris's "question has generated more attention than perhaps any other in Shakespeare's plays besides Hamlet's 'To be or not to be?' " (Shapiro, 2016, no page). Or at the other end of the spectrum, criticism plays suitor to the discourse it seeks to examine, repeating what it regards as self-evident in the texts. So, Rory Rapple suggests that the line in The Comedy of Errors (1594) where Dromio and Antipholus anatomize Nell's body as "spherical, like a globe" (3.2.111), and name Ireland in her buttocks-"I found it out by the bogs" (3.2.114)-"locates Ireland's proper place in the Shakespearean cosmos" (Rapple, 2016, p. 103). Yet there is a considerable body of work that complicates such fixing of Ireland in Shakespeare and within a Shakespearean context. If the Nine Years War and Ireland is Elizabethan England's Vietnam, then they did not just permeate Shakespeare's plays but the drama and culture at large.

The present special issue provides an opportunity to re-examine the texts and debates. In what follows, I seek to enact a critical openness to the issue of how and why Ireland enters the imaginary of a play in this period. This openness takes a number of forms and is, in part, a response to directions within the debate about Ireland in early modern English writing. Willy Maley's work offers a productive direction in its examination of critical unease about topical readings of Ireland in Shakespeare. Some critics, he notes, seem keen "to see a moratorium on the Irishing of Shakespeare" (137). Perhaps a moratorium is justified in the case of The Tempest, where there is now an illuminating body of contrapuntal analyses of the play's Irish subtexts and contexts (see Brown, 1994; Fuchs, 1997; Baker, 1997). But Maley's point is that we need an expansion of critical and conceptual parameters through imaginative, "exploratory" approaches to, for example, Ireland and/in Othello (Maley, 2013, pp. 121-138). Others have suggested similarly imaginative leaps. Hopkins (2000) attends to Hamlet's Irish ghosts, from the play's topical imagery of ripeness, suggesting an ageing Queen and Essex's fortunes in Ireland, to the potential Irish origins of Ophelia's name (Hopkins 2000, no page; Hopkins, 2005, p. 46). As Hopkins argues, such representations and allusions carried significant "cultural freight" because Ireland "functioned both as England's threatening Other and as the nearest and most troubling frontier where Protestantism and Catholicism clashed head on" (Hopkins, 2005, p. 45). Fitzpatrick (2002), in a reading that also understands tragedies to be as topically charged as histories, considers Titus Andronicus alongside Elizabethan formulations of Irish barbarism and English expansion into Ireland (127-45). The conjoining of seemingly unlikely (con)textual partners does not need to be about finding Ireland everywhere in the plays of the period-a tendency characteristic of Barton's (1919) study, Links Between Ireland and Shakespeare-but is instead about recognising that plays could be topically diffuse rather than one-directional. This article revisits some of the ways Ireland appears in the plays, and treats representations as a series of reciprocal markings, as well as intertextual echoes. It further argues for a broadening of context, beyond a focus on topical resonance, to allow for a consideration of genre, the imitative nature of dramatic writing in the period, 
and even a theatre company's house style, as important factors that shaped how a text and context like Ireland and the Irish found its way into a play.

\section{2 | MARKINGS}

King James's oft-cited assertion upon viewing documents in the State Paper Office that "we had more ado with Ireland than with all the world besides" (quoted in Baker, 1993, p. 82) conveys the cultural and geographic proximities between the two islands, as well as England's long political interventions in Ireland. Texts of the period dealing with Ireland frequently employ optical or visual terms, as if implying that the effective governance of Ireland was a matter of appropriate perspective and plotting. This logic can be understood with reference to early modern cartography: maps of Ireland are not just emergent graphic renderings of a terrain but are also richly symbolic and ideological (Klein, 2001; Smith, 2006). As the object of surveying English eyes, Ireland gradually becomes viewable and controllable. Maps and cartographic imagery form what Gilles (1994, p. 38) calls "poetic geography" that borrows from and feeds into other discourses. As Smith notes, words such as "plot," "platte," "plan," "mappe," "image," "chart," and "view," "invariably overlap in meaning between a graphic mapping and a narrative strategy of knowledge formulation and utilization," as in Robert Lythe's brief in the 1560s "to take a view of the Irish terrain" and to then record his observations down on "a platte" (479 n.123). Spenser's View similarly employs "plot" to mean a map and also a reformation plan. As Ireland is plotted, or plans drawn up for it, it enters the plots of stage plays. Sometimes this plotting is through spatial and topographic imagery, as in the bawdy blazon of Nell's body in Shakespeare's Comedy of Errors, or in Richard II, where the king's resolve to go personally to Ireland and, as already noted, to "supplant the rough rug-headed kern," introduces the language and logic of uprooting and purification. There is anachronism here, with Richard sounding like an Elizabethan planter, but the image also suggests the long colonial history that precedes the play's immediate context.

Ireland is also the locus of plots against kings, as in 2 Henry VI, where York's challenge to the king sees him draw on a shape-shifting, Hibernized Jack Cade, and finally bring "an army of Irishe" (Scene 23) into London. In Marlowe's Edward II (1592), Ireland is similarly figured as an alternate power base for the king's beloved, Gaveston, who has been banished there, but also, atypically, as a safe haven for him and, in this Marlovian history, a queer space where Edward and Gaveston might find respite from political opponents. Ireland is a fleeting presence in the drama-it as if there is no cartographic or graphic completeness yet available in the culture-and where it does appear, it does so largely as a set of images or micro-impressions, or even as the obscene Other that haunts England (Collins, 2015, pp. 126-38). The sense of Ireland as an image or fragment is matched at the level of language, with Irish only barely heard in the plays of the period. Characters designated as Irish in the plays, such as Captain Whit in Ben Jonson's Bartholomew Fair (1972; 1614), or MacMorris in Henry V, or MacChane in Drayton, Munday and Wilson's Sir John Oldcastle (1984; 1599), may speak in a broken English, but they are nonetheless shown to be immersed in an Anglophone world. An exception here is Captain Thomas Stukeley (1596), the only play from the period to include entire scenes set in Ireland-although in Thomas Heywood Four Prentices of Ireland (1943; 1594) one of the four brothers briefly lands on the Irish coast-and to feature a scene where the characters converse in Gaelic (see O'Neill, 2007). Stukeley complicates arguments that Ireland could not be treated head on in the drama (Clare, 1999), but significantly, a print version of the play did not appear until 1605. As Rutter (2017) argues, the play's depiction of its protagonist, who fights against O'Neill before turning against his own Queen, probably made it very difficult to perform in the last years of Elizabeth's reign (129).

To seize upon overt references, be it a full scene set in Ireland as in Stukeley, or the topical analogy to Essex in Henry V's final chorus, is to reveal and to confront textual evidence of the imprint of the Irish wars on drama and theatre. Seamus Heaney (1995) long ago addressed such challenging coincidences, or how "English pentameter marched in step with the invading English armies of the late Tudor period" (29). Elizabethan governors in Ireland framed policy as a mark: "The iron is now hot," wrote Sir Henry Sidney, "apt to receive what prynte shall be stryken" 
(quoted in Smith, 2006, p. 45). Plays imprint or mark Ireland in their very inclusion of it in their printed text. This literal marking suggests the symbolic nature of such incorporation into the fabric of a play, as Heaney highlights when, digressing from his focus on Marlowe's "Hero and Leander," he briefly thinks of Gaveston's banishment in Edward II as the "relegation of Ireland to the status of non-place" and its positioning as "an annex of the civil conquerors and the locus of barbarism that had to be held at bay" (31). Context becomes all here: not mere contemporary Elizabethan backdrop to history plays chronicling the rise and fall of medieval kings, but an agential thing that shapes meaning within the play itself. Through this heuristic, direct references to Ireland in the drama are to be accounted for contextually. Among such over-looked direct references is the dual mention of the legendary Irish kerns, or foot soldiers, in Kyd's tragedy, Soliman and Perseda (1901; c. 1592). An English knight includes among his boast, "Against the light foot Irish have I served, /And in my skin bear tokens of their skenes" (1.3.21-22). Another character Basilisco, also boasting of his martial accomplishments, has fought with the Irish: "Upon a time in Ireland I fought, /On horseback with an hundred Kerns" (1.3.94-95). The play incorporates Ireland, but in this scene, Ireland also marks characters.

Plays that mention Ireland and the Irish, while not necessarily advocating policy in Sidney's terms, might be said to entail an appropriative gesture towards Ireland, and the translation of it into an idea for the English imaginary. Arguably, then, references to Ireland and the Irish in Elizabethan drama constitute forms of cultural colonialism, or expressions of political desires, and after 1603 with the defeat of O'Neill's forces, political realities, as English sovereignty over Ireland was effected. I pose this hypothesis in order to give allow for the range of meanings that may attach to Ireland in Shakespeare and early modern drama. O'Toole is perhaps too quick, therefore, in debunking claims for a specific Irish response to Shakespeare, which might be said to begin as an attenuated one because of the historically colonial relationship that pertained when the plays were composed and which is arguably encoded in them (see Lonergan, 2010, pp. 343-49).

However, as Heaney elaborates in his essay, over-determining how Ireland appears in an English Renaissance literary text or what it signifies contextually can lead us to a point where "imaginative literature is read simply and solely as a function of an oppressive discourse, or as a reprehensible masking" (32). Criticism must be careful not to presume the question, or indeed to already know the answer, namely, that the representation of Ireland in English Renaissance drama is an ideological function of the contemporaneous Irish wars and, more historically, English colonialism in Ireland. This interpretation has been the dominant in the hermeneutics of why and how Ireland features in Shakespeare and his contemporaries. It has had multiple iterations but can be traced back to new historicism and cultural materialism and, even more particularly to Greenblatt's (1994) "Invisible Bullets" essay, which briefly alluded to Ireland, and Dollimore and Sinfield's (1985) "History and Ideology: the Instance of Henry V," which more expansively treated of the Elizabethan problem of Ireland as being worked out and finding its imaginary resolution through the play's plot of English conquest in France. Criticism that followed on from this work, such as Highley's (1997) monograph, Shakespeare, Spenser and the Crisis in Ireland, brought into sharp focus the imprint of English colonialism on the literary imagination. Critical work further demonstrated how texts treating of Ireland, be it in a sustained manner as in John Derricke's Image or Spenser's Faerie Queene, or in passing, as in memories of taming Ulster that manifest in Sir Philip Sidney's sonnet sequence Astrophil and Stella, formally registered the intractability of Elizabethan policies towards Ireland (Fogarty, 2006, p. 147). Far from functioning as ideological containers for the problem of Ireland, literary texts instead powerfully disclose at the level of their form the uncertainty about Elizabethan policy and indeed English futures in Ireland.

Yet the attribution of formal contradiction or indeterminacy in a text to extra-textual ideologies, while persuasive, risks reducing the texts to a reflex of larger and unassailable political processes. Elizabethan colonial wars in Ireland come to be understood not just as a shaping context, but as the most significant determinant of meaning. Criticism risks repeating the representational strategies of colonialist discourse, and all the more so because the texts essayed represent a predominantly Anglophone world (Palmer, 2001, pp. 4-5). However, there is critical value in attending to Ireland as a text in English Renaissance drama where the critical act of noticing representations of Ireland produces new lines of argument. One new approach as an alternative to a mode of reading that sees Ireland as marked or recorded into English culture is to regard Ireland as marking plays, such that the descriptor "English 
Renaissance drama" is no longer sufficiently encompassing or denotes merely a period and location rather than a national prefix or designation. The archipelagic and so-called British perspectives signal something of this direction in their thinking beyond the nation, although in Shakespeare studies, the introduction of Ireland into criticism on Henry V had already complicated the exclusivity of Shakespeare's "English" histories to the point of rendering the play synonymous with Ireland (Murphy, 1996). Maley's work advances pathways beyond an Irish focus to argue for reading the plays as negotiations of a multi-nation state, or the problem of Britain as opposed to simplistic staging of little England (Maley, 1997; Maley, 2007). The four captains' scene in Henry V is only the most obvious expression of a working through of the multi-nation state. As John Kerrigan notes, "Ireland does not fade out of Shakespeare after Henry V" (2008, p. 19) but unfolds in Macbeth. Shakespeare's "Scottish play" is in fact "deeply implicated in archipelagic issues" and it is Macbeth, argues Kerrigan, more so than The Tempest, that most readily correlates with Ireland (18-19). Other critics have located a working through of the British-Irish polity well after and beyond Shakespeare, with Morrissey (2016) highlighting how "15 years after Shakespeare's Henry V, Jonson is still wondering how the island's various parts fit together" (373) in the Irish Masque (1613).

But why limit critical perspective to the archipelago when plays themselves venture further afield, and when the preeminent theatre in early modern London was called the Globe? Ireland's representation, along with Scotland and Wales, in plays performed on the London stage, can be viewed as a part of a broader consciousness of cultural difference, of the multi-nation state, and even of pluralism. Baker (2014), reflecting on the limits of the archipelagic criticism, highlights how Englishness was itself transnational and that the identities of early modern Ireland-New English, Old English, Gaelic Irish-were "crude approximations that had been mapped onto intricate dialectical processes of identity formation, imposing a stasis and definition where, really, there was none" (p. 31). Recent work on early modern drama, which has turned attention to its diverse geographies, cultural vocabularies, and a general working through of identity as malleable, offers an important direction for work on plays that feature Ireland. Griffin (2010) highlights how George Peele's Battle of Alcazar (1589), which features Captain Thomas Stukeley's ambition to become King of Ireland, contains "transnational energies" (97). This unsettles previous assumptions that Peele's play exemplified the trademark heroism and patriotism of the Admiral's Men's (Feldman \& von Rosador, 2007, p. 329). Similarly, Joanne Roby challenges readings of Stukeley as the popular English hero to suggest that Peele's play, and the later play Stukeley, present a more complex picture of identity, in which Englishness and Catholicism coexist and where audiences are encouraged to "enjoy dramatic representations of extravagant heroic feats regardless of the protagonist's problematic identity" (40). As Roby (2011) cautions, "readings that focus on one or two relationships or allegiances erase the complexity and dangers in the play and the world in which it was written" (42). There is a lesson here for criticism on Ireland in the drama to think outside the nation, to attend to the intersection of character types or identity valences, and to enact a less myopic and Anglo-centric sense of "forms of nationhood" in the writing of the period. Something of this approach is evident in recent Henry $V$ criticism too, where Ireland is treated as one among the play's variegated texts, subtexts and contexts. For example, Loughnane (2016), the play's editor for the New Oxford Shakespeare, uses a series of epigraphs to reflect trends in its critical reception. These capture how prevalent Ireland is in critical thinking on the play, but Loughnane moves debate in new directions in describing Henry $V$ as "a truly international play: one scene is performed almost entirely in French, and Harry's multinational army is brought to life with the dialectical strains of the Welsh, Scot, and Irish soldiers" (1532).

It is interesting to reflect on the drivers of these shifts in critical discourse and emphases: in the context of a new edition of Shakespeare's works, there's an imperative to convey the playwright's international reach. Loughnane also writes within the current of criticism on the Shakespearean history play, which is seen as "sustaining a questioning attitude towards the political rather than a consistent ideological resolution of it" (Cavanagh, 2000, p. 79). Previous critical work on Ireland in Shakespeare and Renaissance drama has been said to bear the imprint of its present, especially developments in the Northern Ireland peace process (O'Neill, 2013). In this formulation, critical emphasis on the plays' pluralism, and on their disclosure rather than activation of colonialist and national stereotypes, is part of the more flexible identity politics within relations between Ireland and Britain. Extending this argument to recent work, one could see its interest in the intersection of cultures and national types in early modern plays as informed by 
contemporary globalisation, as well as a search for earlier histories of transnational exchange that counter the renewal of nationalist ideologies in Europe, as evidenced most notably by Brexit, and in the United States, as evidenced by the election of Donald Trump on a platform of "America first." Writing within this cultural context, a politically progressive critic of Shakespeare and early modern drama might wish to find in the plays and texts of the period a cultural range, an unresolved question about national identity politics. From this perspective, MacMorris' "What ish my nation?" directs itself not just to 1599-and the uncertain outcome of the wars in Ireland-but to the undesirability of over determining the national through history.

Consideration must also be given for the capacity of play to make meaning within its own frame: the dynamic of a play in which Ireland or the Irish may feature is not fully or resolutely reducible to the context of the Irish wars. The domestic tragedy, A Warning for Fair Women (1904; 1599), is illustrative here. It opens in medias res with an exchange between George Sanders, a London merchant, and Captain George Browne, who has just made each other's acquaintance. Sanders thanks Browne for "his good discourse of Ireland/Where it seems you have been resident" (1.1.3) and what follows is a brief conversation that reveals how Ireland enters the drama as a contemporary, if passing, news item:

BROWNE True, sir, I have been there familiar,

And am no better known in London here.

Than I am there, unto the better sort;

Chiefly in Dublin, where ye heard me say,

Are as great feasts as this we had to-day.

SANDERS So have I heard. The land gives good increase

Of every blessing for the use of man;

And 'tis great pity the inhabitants.

Will not be civil, nor live under law.

BROWNE As civil in the English Pale as here,

And laws obeyed, and orders duly kept;

And all the rest may one day be reduced.

SANDERS God grant it so! (1.1.7-18).

This dialogue offers a typically Elizabethan account of Ireland, perhaps with specific echoes of Spenser's View. In this play, however, the present state of Ireland is secondary to plot, which dramatises the real-life murder, in 1573, of one George Sanders by George Browne, who had fallen in love with Sanders' wife. It is her arrival that interrupts the opening exchange between the two men: "I like your talk of Ireland so well" remarks George, "That I could wish time had not cut it off (1.1.25-26). While Browne's hope for a subjugation beyond the Pale takes on an irony in light of his subsequent murderous actions, the play does not capitalize on his country of birth; he has acculturated himself into London life. There is no broken English speech, or any other markers of Irish-or Anglo-Irish-identity that one finds in other Elizabethan plays. And, in the trial scene, Browne's nationality is presented factually: 'What countryman are ye born?' " asks the court official, to which Browne replies "Of Ireland, and in Dublin" (4.4.51-52). Of course, in a performance, Browne's self-professed identity status could have been marked out through accent, clothing and bodily movement on stage. However, in this domestic tragedy there is less concern with questions about his "nation" than with Browne as a manifestation of human immorality and as a negative exemplum: "Of all the cursed, I the most accursed. / All careless men, be warned by my end, /And by my fall, your wicked lives amend" (4.5.90-91). The "warning" of the play's title is ultimately directed at Anne Sanders, whose complicity in the murder has been revealed. The final scene features a contrite Anne just before her execution, seeing her children for the last time and bequeathing to them "a book/Of holy meditations" (4.8.147). In the world of the domestic murder play, a genre known for its factuality and localising of action, the emphasis is on threats to social stability, on the illegitimate violence of the criminal and the legitimate state punishment, on Christian ideology and its fault lines (Clark, 2007, 
pp. 70-71). A subject like Ireland enters the domestic murder plot as a grounding detail that links the action to the contemporary lives of the audience. Genre is, then, as important a determinant of Ireland's meaning in Elizabethan drama as historical context.

Attention also needs to be paid to the theatrical medium itself which realises the production of cultural, national, and racialized stereotypes, and at the same time gestures towards the performativity of such roles. That "the language of the stage could dissolve the alien identities that it enabled" (O'Neill, 2007, p. 19) is especially evident in those metatheatrical moments involving sartorial confusion and disguise. In Dekker's Old Fortunatus (1964; 1599), Shaddowe, shedding his disguise as an Irish costermonger, asks "Did I not clap a good false Irish face?" (4.2.98). A more malignant and "real" Irish figure appears in Sir John Oldcastle. Mack Chane has murdered his English master. He activates prejudices and fears about the Irish against the uncertainty of the Essex campaign in Ireland. Yet, in a later scene Mack Chane is temporarily mistaken for the English servant Harpool, who is left with "nothing but a lousy mantle, and a pair of brogues" (Scene 22, 7-8). The unfolding scene of "intricate confusion" (Scene 25, 1), as one character describes it, provides some insight into how Irishness was represented on stage. The Irish mantle, the focus of New English anxieties about degeneration, the contaminating article from which English settlers had to be protected, here becomes a stage property in plays-part of theatre company's inventory. The effect may be a dilution of its potency as a signifier of Irish alterity. Beaumont and Fletcher's The Coxcomb (1966; 1613), where Antonio disguises himself as an Irish footman, appears to suggest that sartorial markers needed to be easily identifiable for the adopted Irish disguise to be convincing and for its comedy to work: "I hope I am wild enough to be known" (2.1) says Antonio, a deictic line that calls for a non-verbal reference to the actor's "Irish" clothes. The period's "stage Irishman" is a fluid text comprising shifting signifiers of Irishness.

In other plays, Irish clothes are not only staged but woven into the visual imagery. John Webster's The White Devil (1612) makes the mantle part of its erotic discourse in an exchange between Zanche, the Moorish servant, and Francisco, here disguised as Mulinassar the Moor:

ZANCHE Fie, sir! As I told you,

Methought you lay down by me.

MULINASSAR So dreamt I;

And lest thou shouldst take cold, I covered thee,

With this Irish mantle. (5.3.228-31).

It could be suggested that the fetishized Irish cloak, the gendered symbol of Irish alterity, denoting the wildness of Gaelic Irish men and the promiscuity of the women, temporarily displaces Zanche's blackness. As Jones and Stallybrass (2007) have shown, however, the mantle changes from a marker of the Irish as the "extreme antithesis of the English" (134) to a hybrid item: worn by Scots, often made of wool imported from Spain and also England and, by the 1610s and 1620s, even part of London high fashion (143). To Webster's audience, then, Mulinassar's fantasy trades in a fashionable commodity that he here extends to Zanche, as much as it does in stereotypical ideas about the Irish. But this is not the first time Ireland has entered Francisco's vocabulary, suggesting that Ireland is in the character's mind-and in the play's world too. Contemplating revenge on Brachiano, he boasts that "Like the wild Irish I'll ne'er think thee dead/Till I can play at football with thy head" (4.1.136-7). "The Irish were notoriously cruel and bloodthirsty," reads one editorial gloss, risking a reiteration of early modern discourses on Ireland as opposed to an examination of them (Luckyj, 2008, p. 80). As Palmer notes, the savagery of the Elizabethan conquest is "winnowed down in English recollection to Irish savagery" (2013, p. 12). Brachiano himself turns to Irish imagery, accusing Vittoria of false and excessive grief: "Ye'd furnish all the Irish funerals/With howling, past wild Irish" (4.2.93-4). The reference is to the Irish lament, or caoineadh, and with it the Gaelic Irish practice of hiring women to mourn the dead. Vittoria is imagined as exceeding the wild Irish women in her performance of grief. Reading historically, we could account for what Fraser and Hansen (2016) call The White Devil's "various elaborations of Irishness" (7) in terms of memories of the Irish rebellion. Fraser and Hansen connect the play's Irish imagery not just 
to memories of Shane O'Neill arriving at Elizabeth's court in 1562 with Irish wolfhounds, and deeper cultural assumptions about Irish lupine wildness, but also with Catholicism: "The White Devil stretches and blurs memorial boundaries of national, sexual, theological and political agency, presenting variously horrible yet attractive reflections of the histories and cultural memories that dominated its Jacobean moment of production" (Frazer and Hansen 10). Webster's play thus engages in a multi-layered referencing of the culture that produced it, in ways that complicate a hierarchy of context to text.

Not only do we have Irish clothes on stage, but the imagining of certain sounds as distinctly Irish. An earlier example occurs in Shakespeare's As You Like It (1599), where Rosalind takes charge of animal imagery and culturally wild sounds that in Webster are deployed to denigrate Vittoria. "Pray you no more of this, 'tis like the howling of Irish wolves against the moon" (5.2.105-06), she says, upbraiding Orlando for his Petrarchan language of love and adoration of the absent beloved. In Shakespeare's source text, Thomas Lodge's Rosalind, the reference is to Syrian wolves, but Shakespeare's Rosalind brings matters closer to home, and into the sounds of theatrical performance, in a substitution that may imply a topical allusion to Essex's much anticipated expedition to Ireland in 1599. The simile may activate the lupine imagery similar to that in Webster's play. The Arden editor glosses the line by noting that "Spenser observed (in A View) that the Irish thought some men would be transformed annually into wolves, and paid special honour to the moon in the hopes of avoiding this fate" (Dusinbere, 2006, p. 326), but also notes the potential resonance with Elizabeth as moon goddess. As Butler (2013) points out, however, it is not clear which "culture's lovers, Ireland's or England's, sing countless lovelorn praises to unobtainable mistresses" (97). Rosalind's line implies a critique of those Elizabethans who continue to worship an ageing Cynthia, as much as it denigrates the Irish. But this is only one part of the commingling of Ireland and England in a play where Rosalind has alluded to her previous incarnation as "an Irish rat" (3.2.173). It is tempting to interpret these references as contextual mnemonics or slips, that bring into focus what would otherwise be an entirely veiled working through of the Elizabethan Irish problem. Butler is keen to avoid direct topical correspondences, but he does suggest that the "play's presentation of forgiveness and reconciliation offers counsel to Essex" (93), with Orlando providing a model in temperance and the managing of passions. Genre and performance thus become crucial to understanding how plays of the period were not only potentially shaped by their historical and cultural moment but also sought to shape it. Shakespeare's pastoral comedy addresses itself towards Ireland, makes it an audible sound in Shakespeare's theatre, and through pastoral's emphasis on renewal through withdrawal, on enmity and succession brought to reconciliation, suggests a subtle mode of response to political crises.

The imagined worlds of plays could also provide a reprieve from the immediate present, or offer in outline alternate political futures. In 1599, Essex's campaign in Ireland, with its use of Scottish soldiers and rumours of a pact with Hugh O'Neill himself, had raised the spectre of a pan-Celtic alliance entering England. England's Joy (1602), Vennar's play in plot only, promises an alternative to such possible futures, with Ireland along with Spain imagined as finally quelled in a drama that seems a reaction to an Elizabethan fin-de-siècle. The plot offers vignettes of recent history -how the tyrant Spain "complotteth with the Irish rebelles," how this "layd open the base ingratitude of Tyrone," and how both were dissipated through "the wisedome and valour of the Lord Mountjoy" (lines 25-7). By 1603, another Celtic constellation was taking shape with James' accession to the English throne. "In an hour," wrote Dekker in The Wonderful Yeare, "two mightie Nations were made one: wilde Ireland became tame on the sudden, and some English great ones that before seemed tame, on the sudden turned wilde" (Dekker, 1966, 28-29). The chiasmic sentence playfully hints at the implications of the new arrival, and the new political reality, with the pacification of Ireland the comic vehicle for Dekker's topical jibe about an influx of Scots into England.

In Jacobean plays, "wilde Ireland" and the Elizabethan Irish wars are placed in the rear view, although the drama arguably remains haunted by some deeper cultural assumptions about Ireland. Marston's Dutch Courtesan (1965; 1604) has Mary Faugh include "swaggering Irish captains" (2.2.30) among Franceschina's clients. In Dekker's Northward Ho (1605), Chamberlain explains to Luke Greenshield that "the towne droopt ever since the peace in Ireland, your captains were wont to take their leaves of their London Polecats, (their wenches I meane Sir) at Dunstable" (1.1.20-21). Ireland appears in Sharpham's Cupid's Whirligig (1986; 1607) as first in the list of places Lord 
Nonsuch, disguised as a "begging soldier" (3.1.21) claims to have fought. In a play of the same year, Middleton's The Phoenix, Ireland's danger is proverbial: the Jeweller's wife asks "Would he venture his body into a barber's shop when he knows 'tis as dangerous as a piece of Ireland?" (Scene 5, line 6-7). Jonson's Epicene (1609) has La Foole boast about being "knighted in Ireland" (1.4.60), generally glossed by the play's editors as a reference to Essex's doling out of titles during his campaign in Ireland, to the displeasure of the queen. In the same play, Morose mentions Ireland, along with Constantinople and Virginia (2.5.131). Editors have repeatedly explained this as Ireland's reputation as a place for wastrels to rescue their fortunes (Partridge, quoted in Dutton, 2003, p. 170), but in the context of the plantation of Ulster with English and Scottish settlers, the line points to the play's present, and indeed future. Cooke's Greene's Tu Quoque, or The City Gallant (1611) describes Ireland in similar terms, with a gentleman Staines, ensnared by a usurer, complaining "I dare not walk abroad to see my friends, for fear the serjeants should take acquaintance of me: my refuge is Ireland, or Virginia: necessity cries out" (no page). Alongside this perception persists the proverbial view that Ireland and even its soil are dangerous. Captain Albo, the Irish pander in Middleton and Rowley's tragi-comedy, A Faire Quarrell (2007; 1615), makes this complaint in a scene of "roaring" boys, where it is combined with the another proverbial view of the Irish, their apparent sensitivity to flatulence. "I perceive what countryman he is," says Chough, "let me alone with him":

CAPTAIN ALBO Darest thou charge a captain?

TRIMTRAM Yes, and discharge upon him, too.

[Trimtram turns his back to the Captain]

CAPTAIN ALBO Foh, 'tis poison to my country, the slave has eaten pippins! O, shoot no more, turn both thy broadsides rather than thy poop! 'Tis foul play: my country breeds no poison. I yield, the great O'Toole shall yield on these conditions. (4.4.97-103)

In Middleton and Webster's city comedy Anything for a Quiet Life (2007; 1621), Young Cressingham says to his mother, "I remember/Ere the land was sold you talked of going to Ireland, /But should you touch there you would die presently" (5.2.270-72); "The country brooks no poison," he explains (273). In a later scene, the mercer Camlet contemplates leaving for the Bermudas, and when Old Franklin instead proposes "Better to Ireland, sir," Camlet replies "The land of ire-that's too near home. My wife will be heard from Helbre to Divelin" (5.2.107-109), that is from the island in the river Dee off West Kirby to across the Irish sea in Dublin. Ireland has been domesticated into the comic lexicon of city comedy, its geographically proximate status used in the service of Walter Camlet's gendered language against his 'braying' wife Rachel.

\section{3 | ECHOES}

In the move from Elizabethan memories of a former "land of ire" to the joke about Ireland's proximity, it is tempting to discern some wider contours to representations of Ireland in Jacobean drama. When taken as an aggregate, the series of micro references map onto a larger historical narrative. The incorporation of Ireland and the Irish into the vocabulary and space of Jacobean plays, and significantly the extent to which that incorporation is somewhat attenuated, reflects contemporary political realities. Sir John Davies' hope that under King James, there would be "no difference or distinction, but the Irish Sea betwixt us" (quoted in Murphy, 1999, p. 145) finds a kind of dramatic correlative in those plays that casually work into their plots the dutiful Irish footman, as in Dekker's Honest Whore, Part 2 (Dekker, 1605). It is interesting to note that playwrights like Middleton did proffer overt political and ideological commentaries on recent Irish and British history, as in his pamphlet The Peace-maker (1618; 2007): "Ireland, that rebellious outlaw, that so many years cried blood and death (filling her marish grounds with massacres, affording many preys of slaughtered bodies to her ravenous wolves, and in their wombs keeping brutish obsequies), would know no lord, but grew more stubborn in her chastisement till his white ensign was displayed, then she came running with this hallowed text in her mouth: Beati pacifici" (79-85). As with Davies' text, which ends up narrativising English 
interventions in Ireland as a series of failures, plays too cannot quite fully render the Irish-or Ireland-and "continue to stress the inassimilable alterity of the country" (Fogarty, 2006, p. 159). However, to attribute an ideological work to Jacobean plays over determines their micro-mentions of Ireland and positions historical context as the guarantor of dramatic meaning.

To the factors accounting for why Ireland enters the imaginary of plays should be added intertextuality. References to Ireland, when collated, can seem like an echo chamber, or a set of commonplaces that find repetition in plays, often without an evident context or in ways that seem incidental to plot. So, the Irish objection to farting is so proverbial as to stand in need of no elaboration in Marston's The Malcontent (1975; 1604), where Mendoza's remark, "The duke hates thee" cues up Malevole's reply, "As Irishmen do bum-cracks" (3.3.49-50). Irish words and, as already noted, sounds appear in the plays, in ways that suggest repetition, or a set of phrases that can be transposed from one context to another. In Eastward Ho (1972; 1605), attributed to Jonson, George Chapman, and John Marston, Gertrude talks to Sindefy of dining with a "lamentable story," and breaks into "O hone, hone, or no nera" (5.1.7), with the eruption into Gaelic going unremarked by her interlocutor. Editors gloss this as a refrain from an Irish lament (Petter, 1972, p. 92). But the line is a refrain more generally, finding its precedent in Oldcastle, where Mack Chane responds to the Mayor in fragmented Gaelic: "Ahone, ahone, ahone, a cree" (Scene 21, line 34), a phonetic version of the Irish "Ochon, a croi," or "alas my heart."

The imitative, intertextual and collaborative nature of dramatic writing must also account for some of the rhetorical parallels and repetitions one finds in representations of Ireland. The similarity between the quarto text of Shakespeare's 2 Henry VI "The wild Onele my lords, is up in Armes /With troups of Irish Kernes that uncontrold / Doth plant themselves within the English pale" and Marlowe's Edward II, "The wild O'Neill, with swarms of Irish kerns, /Lives uncontroll'd within the English pale" (2.2.163-65) comes to mind. The parallels can be understood in terms of Marlowe's hand in Shakespeare's play, the presence of which is, to some scholars, "now undeniable" (Segarra, Eisen, Egan, \& Ribeiro, 2016, p. 249), although others continue to argue for Shakespeare's sole authorship (Freebury-Jones, 2017, p. 139). Marlowe and Shakespeare's kerns reappear in later plays, not just in Macbeth, but in ways that imply the use of the term rhetorically and proverbially, as in Rowley's A Match at Midnight (1622), where Sir Charles says, "imagine me/Some barbarous outlaw, or uncivil kern" and the Widow mentions being "bred here in Ireland/where the women begin the salutation." Repetition and imitation are evident too in the depiction of the loyal Irish footman. In Dekker's Honest Whore, part 2, Bryan is the Irish footman whom Hippolata suspects of infidelity. She calls him an "the Irish Judas / Bred in a Country where no venom prospers/But in the Nations blood hath thus betraid me" (3.1.20203), thus falling back on the proverbial contrast between Ireland being free from snakes but containing venomous inhabitants. Bryan, however, professes unflinching loyalty: "I had rather have thee make a scabbard of my guts, and let out all de Irish puddings in my poore belly, den to be a halfe knave to de I saat, I will never see dyne pnw sweet face more. A mawdid deer a gra, fare de well, fare de well. I wil goe stales Cowes again in Ireland" (3.2.1924). Both the medium, with the footman's broken English, and the message, with the logic of Irish subservience, are echoes of earlier plays, such as Heywood's Four Prentices of London, where the youngest brother, Eustace, having been cast on the Irish coastline, comes upon an Irish funeral procession and immediately obtains the duty of the chief mourner, or as the stage direction has it "makes signes of consent." Eustace is subsequently seen with his Irishman who, as with Dekker's Bryan, expresses duty:

Maister, so Christ save me, I shall waite on thee; wake for thee when thou sleepest, runne for thee when thou biddest, and flye a thy errands, like an arrow from a bow, when thou wantest wine, or meate, to drinke or eate, or any other necessary provision. Now I have left my best friend in the grave, My friendship and my service you shall have. (lines 572-75)

Further echoes are audible in Heywood's unnamed "Irishman," perhaps because we come to them through Shakespeare's Irish, as MacMorris is designated in the Folio, where the idiom, "Christ save me" becomes a refrain within a larger representational refrain: "By Chrish la, tish ill done" (3.2.89), "so Chrish save me" (93), "so Chrish save me" (106), "so Chrish sa' me, la!" (114), "So Chrish save me" (134). It appears in Stukeley, in O'Hanlon's "Cresh bllesh 
us" (Scene 7, 17). As much as he is synonymous with his "nation," MacMorris is also a tissue of quotations of Irish characters on the English stage. In accounting for Ireland as a series of echoes, one might explain dramatic representations-or should we say repetitions-in terms borrowed from Jameson (2003) on postmodern cultural productions, that is to interpret them as a kind of "collective unconscious in the process of trying to identify its own present at the same time that they illuminate the failure of this attempt, which seem to reduce itself to the recombination of various stereotypes of the past" (296).

The argument I am proposing here, then, is that Ireland does not so much appear in the plays of the period, as reappear, and that it does so for a variety of reasons. The theatrical company under whose auspices and patronage a play emerges must also be considered as a factor in the production of the text of Ireland. The Battle of Alcazar, Stukeley, Four Prentices, Old Fortunatus, Sir John Oldcastle each have an Irish dimension, such as an Irish character (Alcazar, Stukeley, Oldcastle, Prentices), a scene set in Ireland (Stukeley, Prentices), or some Gaelic words and phonetically rendered phrases (Stukeley, Prentices, Oldcastle); they are also all plays in the Admiral's Men repertory, which begs the question as to the politics and ideology of a company. Patronage, by implication, becomes a factor, since the company's patron, Charles Howard, was a known opponent of Essex at court. Oldcastle has been interpreted as a response to the potentially pro-Essex angle of Shakespeare's Henry V (Whitfield White, 2006, p. 87). In this context, the depiction of the disloyal Irish servant Mack Chane in an Admiral's Men play suggests a foray into Essex's failure to quell rebellion and those contemporary rumours about his proximity to Hugh O'Neill. Political factions, their expression in and through Elizabethan policy towards Ireland, and their manifestation through aristocratic patronage of theatre companies, are all part of the dynamic of Ireland in the drama. Tom Rutter highlights this when he notes affinities between the Admiral's Men's Stukeley and Shakespeare's Henry IV for the Lord Chamberlain's Men as not merely reflective of "the tendency of Elizabethan dramatists to learn from their competitors' success, but also their common engagement with certain contemporary developments" (127). Stukeley's inclusion of Shane O'Neill suggests to Shakespeare and his company a model to both consider in dealing with topically sensitive subjects, and one to potentially depart from, or avoid altogether.

That this essay has found itself circling back to the interconnections between drama and the topically charged is to recognise that plays in this period are always already political, ideological, and contextually embedded. But this is not the same as saying that plays have anything approaching a definitive position on a question, subject or problem like Ireland. As Jean Howard (1994) argues, Shakespearean and early modern plays "frequently accommodated ideologically incompatible elements" (7) a contention that should inform interpretations of how Ireland and the Irish are figured therein. To focus on these subject categories is to engage in a micro-narrative of early English drama. Yet these subjects map on to larger narratives about interrelations between Britain and Ireland in the period that have their own echoes through history, and also into the present. It is the mix of temporal registers, past texts being read in the multiple contexts of their production, and read in and through the critic's present, that one apprehends the complexities-and indeed responsibilities-of thinking critically and with openness about Ireland in Shakespeare and beyond. The Druid production with which I opened trades in that enigmatic but attractive terrain of "beyond," adapting Shakespearean histories as sites not merely of colonial thought and colonial memory to be exorcised but also as texts that refuse reduction to a master context, or to an overarching history. That the production cut so many of the plays' Irish references is itself an instance of striving for the beyond-beyond a pathological fixation with how Ireland features, beyond the stage Irishman, beyond an imagined desire to locate a Shakespeare in or for Ireland. Druid flipped the perspective: it made its production not about Ireland, or even Shakespeare, but about a set of plays, with their own deeply constructed worlds, and about a theatrical experience. In that move, critical debate about Ireland in early modern English drama might find a productive direction, turning its attention away from the narrowly topical and towards the variety of factors and contexts that brought "the land of ire" into the fabric of so many plays in the period.

\section{ENDNOTES}

${ }^{1}$ Production details are available at http://www.druid.ie/druidshakespeare/about/

2 All quotations from Shakespeare are to Loughnane (2016). 


\section{ORCID}

Stephen O'Neill @ http://orcid.org/0000-0002-4674-9127

\section{WORKS CITED}

Baker, D. J. (1993). Off the map: Charting uncertainty in Renaissance Ireland. In B. Bradshaw, A. Hadfield, \& W. Maley (Eds.), Representing Ireland: Literature and the origins of conflict, 1534-1660. (pp. 76-92). Cambridge: Cambridge UP.

Baker, D. J. (1997). Where is Ireland in The Tempest? In M. T. Burnett, \& R. Wray (Eds.), Shakespeare and Ireland. (pp. 68-88). London: Palgrave.

Baker, D. J. (2014). Britain Redux. Spenser Studies, 29(1), 21-36.

Barton, P. D. (1919). Links between Ireland and Shakespeare. Dublin: Maunsel.

Bowers F. (Ed.) (1966). Dramatic Works in the Beaumont and Fletcher Canon. Cambridge.

Brown, P. (1994). This thing of darkness I acknowledge mine: The Tempest and the discourse of colonialism. In J. Dollimore, \& A. Sinfield (Eds.), Political Shakespeare: Essays in cultural materialism (2nd ed.). (pp. 48-71). Manchester: Manchester UP.

Butler, C. (2013). The howling of Irish wolves: As You Like It and the Celtic Essex Circle. In W. Maley, \& R. Loughnane (Eds.), Celtic Shakespeare: The bard and the borderers. (pp. 89-102). Farnham: Ashgate.

Cavanagh, D. (2000). Shakespeare and history. In D. Cartmell, \& M. Scott (Eds.), Talking Shakespeare: Shakespeare into the millennium. (pp. 70-82). New York: Palgrave.

Clare, J. (1999). 'Art made tongue-tied by authority': Elizabethan and Jacobean dramatic censorship (2nd ed.). Manchester: Manchester UP.

Clark, S. (2007). Renaissance drama. London: Polity.

Collins, N. (2015). 'This prison where I live': Ireland Takes Centre Stage. Cahiers Élisabéthains, 88(1), 125-138.

Cooke, J. (1912). In J. S. Framer (Ed.), Greene's Tu Quoque, or the city Gallant. London. Retrieved from https://archive.org/ details/greenestuquoqueo20cookuoft

Dekker, T. (1605). The honest whore, Part 2. Digital renaissance editions. Retrieved from http://digitalrenaissance.uvic.ca/ doc/2HW_Q1/complete/

Dekker, T. (1964). In F. Bowers (Ed.), Dramatic Works of Thomas Dekker (Vol. 6). Cambridge: Cambridge UP.

Dekker, T. (1966). In G. B. Harrison (Ed.), The Wonderfull Yeare. Edinburgh.

Dollimore, J., \& Sinfield, A. (1985). In J. Drakakis (Ed.), History and Ideology: The instance of Henry V. Alternative Shakespeares (Vol. 1) (pp. 206-227). London: Routledge.

Drayton, M., Munday, A., \& Wilson, R. (1984). In J. Rittenhouse (Ed.), Sir John Oldcastle. A Critical Edition of Sir John Oldcastle. New York: Garland.

Dusinbere, J. (2006). As you like it. London: Bloomsbury.

Feerick, J. (2014). Strangers in blood: Relocating race in the Renaissance. Toronto: University of Toronto Press.

Feldman, D., \& von Rosador, K. T. (2007). Lost plays. In G. Taylor, \& J. Lavagnino (Eds.), Thomas Middleton: The collected works. (pp. 329-333). Oxford: Oxford UP.

Fitzpatrick, J. (2002). Foreign appetites and alterity: Is there an Irish context for Titus Andronicus? Connotations, 11(2-3), 127-145.

Fogarty, A. (2006). Literature in English, 1550-1690: From the Elizabethan settlement to the Battle of the Boyne. In M. Kelleher, \& P. O'Leary (Eds.), The Cambridge history of Irish literature. (Vol. 2). Cambridge: Cambridge UP.

Fraser, P., \& Hansen, A. (2016). 'The white devil': A critical reader. London: Bloomsbury.

Freebury-Jones, D. (2017). Did Shakespeare really co-write 2 Henry VI with Marlowe? ANQ: A Quarterly Journal of Short Articles, Notes and Reviews, 30(3), 137-141.

Fuchs, B. (1997). Conquering islands: Contextualizing The Tempest. Shakespeare Quarterly, 48(1), 45-62.

Gilles, J. (1994). Shakespeare and the geography of difference. Cambridge: Cambridge UP.

Greenblatt, S. (1994). Invisible bullets: Renaissance authority and its subversion. In J. Dollimore, \& A. Sinfield (Eds.), Political Shakespeare: Essays in cultural materialism. (pp. 18-47). Manchester: Manchester UP.

Griffin, E. (2010). 'Spain is Portugal/and Portugal is Spain': Transnational attraction in the Stukeley plays and The Spanish Tragedy. Journal for Early Modern Cultural Studies, 10(1), 95-116.

Hadfield, E. (1997). "Hitherto she ne're could fancy him": Shakespeare's "British" plays and the exclusion of Ireland. In M. Burnett \& R. Wray (Eds.), Shakespeare and Ireland. (pp 47-63). London: Macmillan. 
Heaney, S. (1995). Extending the alphabet: On Christopher Marlowe's 'Hero and Leander'. In The redress of poetry. (pp. 17-37). Oxford: Oxford UP.

Heywood, T. \& Weber, M. A. (Ed.) (1943). The four prentices of London (A critical, old-spelling ed.). Tulane University. Retrieved from https://search-proquest-com.jproxy.nuim.ie/docview/288228579?pq-origsite=summon\&https://search. proquest.com/pqdtglobal

Highley, C. (1997). Shakespeare, spenser, and the crisis in Ireland. Cambridge: Cambridge UP.

Hopkins, L. (2000). 'Ripeness is all': The death of Elizabeth in drama. Renaissance Forum, 4/2. Retrieved from http://www. hull.ac.uk/renforum/v4no2/hopkins.htm

Hopkins, L. (2005). Shakespeare on the edge: Border-crossing in the tragedies and the henriad . Farnham: Ashgate.

Hopkinson, A. F. (Ed.) (1904). A Warning for Fair Women. London. Retrieved from https://archive.org/details/ cu31924013127331

Howard, J. E. (1994). The stage and social struggle in early modern England. London: Routledge.

Jameson, F. (2003). The politics of postmodernism. Durham: Duke UP.

Jones, A., \& Stallybrass, P. (2007). 'Rugges of London and the Diuell's band': Irish Mantles and Yellow Starch as Hybrid London Fashion. In L. C. Orlin (Ed.), Material London, ca. 1600. (pp. 128-149). Pennsylvania: University of Pennsylyvania Press.

Jonson, B. \& Dutton, R. (Ed.) (2003). Epicene, or the silent woman. Manchester: Manchester UP.

Jonson, B., Chapman, G., \& Marston, J. (1972). In C. G. Petter (Ed.), Eastward Ho!. London: Methuen.

Kerrigan, J. (2008). Archipelagic English: Literature, history, and politics, 1603-1707. Oxford: Oxford UP.

Klein, B. (2001). Maps and the writing of space in early modern England and Ireland. New York: Palgrave.

Kyd, T. (1901). Soliman and Perseda. In F. S. Boas (Ed.), Works of Thomas Kyd. Oxford: Clarendon Press. Available at https:// archive.org/details/cu31924013131614

Lonergan, P. (2010). 'I found it out by the bogs': Reviewing Shakespeare in Ireland. Shakespeare, 6(3), 343-349.

Loughnane, R. (2016). In G. Taylor, et al. (Eds.), Henry V. New Oxford Shakespeare: The Complete Works. Oxford: Oxford UP.

Luckyj, C. (2008). In J. Webster (Ed.), The white devil. London: Bloomsbury.

Maley, W. (1997). 'This sceptred isle': Shakespeare and the British problem. In J. J. Joughin (Ed.), Shakespeare and national culture. (pp. 83-108). Manchester: Manchester UP.

Maley, W. (2007). 'A thing most brutish': Depicting Shakespeare's multi-nation state. Shakespeare, 3, 179-101.

Maley, W. (2013). Othello and the Irish question. In W. Maley, \& R. Loughnane (Eds.), Celtic Shakespeare: The bard and the borderers. (pp. 121-138). Farnham: Ashgate.

Marston, J. (1965). In M. L. Wine (Ed.), The Dutch Courtesan. London: Methuen.

Martson, J. (1975). In G. K. Hunter (Ed.), The Malcontent. London: Methuen.

Middleton, T. (2007). The peace-maker. In G. Taylor, \& J. Lavagnino (Eds.), Thomas Middleton: The collected works. Oxford: Oxford UP.

Middleton, T., \& Rowley, W. (2007). A faire quarrell. In G. Taylor, \& J. Lavagnino (Eds.), Thomas Middleton: The collected works. Oxford: Oxford UP.

Middleton, T., \& Webster, J. (2007). Anything for a quiet life. In G. Taylor, \& J. Lavagnino (Eds.), Thomas Middleton: The collected works. Oxford: Oxford UP.

Morrissey, L. (2016). 'Obedience doth not well in parts': Jonson, Shakespeare, and the Atlantic Archipelago. Shakespeare, 12(4), 364-374.

Murphy, A. (1996). Shakespeare's Irish history. Literature and History, 5, 38-59.

Murphy, A. (1999). But the Irish Sea betwixt us: Ireland, Colonialism and Renaissance literature. Lexington: University Press of Kentucky.

O'Neill, S. (2007). Staging Ireland: Representations in Shakespeare and Renaissance drama. Dublin: Four Courts Press.

O'Neill, S. (2013). Beyond MacMorris: Shakespeare, Ireland and critical contexts. Celtic Shakespeares: The Bard and the Borderers. (pp. 245-258). Farnham: Ashgate.

O'Toole, F. (2015). Druid Shakespeare. Programme.

Palmer, P. (2001). Language and conquest in early modern Ireland: English Renaissance literature and Elizabethan imperial expansion. Cambridge: Cambridge UP.

Palmer, P. (2013). The severed head and the grafted tongue: Literature, translation and violence in early modern Ireland. Cambridge: Cambridge UP. 
Parker, P. (1996). Shakespeare from the margins: language, culture, context. Chicago: Chicago UP.

Rapple, R. (2016). Shakespeare, the Irish and military culture. In R. Malcolm Smuts (Ed.), Oxford handbook of the age of Shakespeare. (pp. 103-120). Oxford: Oxford UP.

Roby, J. W. (2011). Turning Catholic: Peele's The Battle of Alcazar and Captain Thomas Stukeley. Parergon, 28(1), $25-42$.

Rutter, T. (2017). Shakespeare and the Admiral's men: Reading across repertories on the London stage, 1594-1600. Cambridge: Cambridge UP.

Segarra, S., Eisen, M., Egan, G., \& Ribeiro, A. (2016). Attributing the authorship of the Henry VI plays by word adjacency. Shakespeare Quarterly, 67(2), 232-256.

Shapiro, J. (2016). 'What ish my nation?' Shakespeare's Irish connections. The Irish Times [Online] 23 April 2016. Retrieved on 30 October 2017 from https://www.irishtimes.com/culture/stage/what-ish-my-nation-shakespeare-s-irish-connections1.2619173

Sharpham, E. \& Petter, C. G. (Ed.) (1986). A critical old spelling edition of the works of Edward Sharpham. New York: Garland.

Smith, W. (2006). Map-making, landscapes and memory: A geography of colonial and early modern Ireland, c.1530-1750 . Cork: Cork UP.

Vennar, R. (1931). The plot of the play, called England's Joy. In W. W. Greg (Ed.), Dramatic documents from the Elizabethan playhouses. Oxford: Clarendon Press.

Whitfield White, P. (2006). Shakespeare, the Cobhams and the dynamics of Theatrical Patronage. In P. Whitfield White, \& S. R. Westfall (Eds.), Shakespeare and theatrical patronage in early modern England. (pp. 64-89). Cambridge: Cambridge UP.

Stephen O'Neill is a senior lecturer in the Department of English, Maynooth University-National University of Ireland Maynooth. He is the author of two books, Shakespeare and YouTube: New Media Forms of the Bard (Arden Shakespeare, 2014) and Staging Ireland: Representations in Shakespeare and Renaissance Drama (Four Courts, 2007) and the editor of Broadcast Your Shakespeare (Arden Shakespeare, 2017). With Janet Clare, he edited Shakespeare and the Irish Writer (UCD Press, 2010). His articles and book chapters include work on Hip-Hop Shakespeare, social media Shakespeares, and Shakespeare and quotation. With Maurizio Calbi, he edited the special issue of Borrowers and Lenders on "Shakespeare and Social Media" (2016).

How to cite this article: O'Neill S. Beyond Shakespeare's land of ire: Revisiting Ireland in English Renaissance drama. Literature Compass. 2018;15:e12491. https://doi.org/10.1111/lic3.12491 